\title{
Do queens of bumblebee species differ in their choice of flower colour morphs of Corydalis cava (Fumariaceae)?
}

\author{
Łukasz Myczko, Weronika Banaszak-Cibicka, Tim H. Sparks, Piotr Tryjanowski \\ Institute of Zoology, Poznań University of Life Sciences, Wojska Polskiego 71C, 60-625, Poznań, Poland
}

Received 6 June 2014 - Revised 18 September 2014 - Accepted 6 October 2014

\begin{abstract}
Bumblebee queens require a continuous supply of flowering food plants from early spring for the successful development of annual colonies. Early in spring, Corydalis cava provides essential nectar and pollen resources and a choice of flower colour. In this paper, we examine flower colour choice (purple or white) in C. cava and verify the hypothesis that bumblebee queens differ in their choice of flower colour. A total of 10,615 observations of flower visits were made in spring 2011 and spring 2014 near Poznań, western Poland. Our results suggest that Bombus lucorum/cryptarum used purple flowers less, while Bombus terrestris used purple flowers more and Bombus hortorum showed no preference. Therefore, the colour morphs of $C$. cava are probably coevolutionary adaptations to the development of another part of the insect community which has different colour preferences.
\end{abstract}

\section{Bombus lucorum / Bombus cryptarum / Bombus terrestris / Bombus hortorum / foraging behaviour / colour choice}

\section{INTRODUCTION}

Pollinators are often considered crucial species in ecosystems (Williams and Osborne 2009; Winfree 2010). Bumblebees pollinate a wide range of plants in both agricultural and natural habitats (e.g. Heinrich 2004; Goulson 2010; Osgathorpe et al. 2012). They live in annual colonies that are founded by single queens (Heinrich 2004; Goulson et al. 2002). When a queen emerges from hibernation in spring, she feeds on pollen and nectar until her ovaries develop. She then tries to find a suitable nesting site. Early colony development is in fact a critical period characterised by a high rate of colony failure

Electronic supplementary material The online version of this article (doi:10.1007/s13592-014-0326-x) contains supplementary material, which is available to authorized users.

Corresponding author: $Ł$. Myczko, lukasz.myczko@up.poznan.pl Manuscript editor: James Nieh
(Wilson 1971; Oster and Wilson 1978). A strong selection is evident, partly caused by ergonomic restrictions due to mismatching functional traits of plants and insects (Wilson 1983). For the development of their annual colonies, bumblebees require a continuous supply of flowering food plants from early spring to late summer, as is usually provided in perennial semi-natural habitats (Fussell and Corbet 1991; Corbet 1995).

The melliferous flowers of the herb Corydalis cava (L.) Schweigg and Koerte (Fumariaceae) appear directly before tree foliation. They precede and supplement shrub and tree flowering, so can be an important food supply for pollinators in early spring. The complex flower morphology of the species indicates a co-evolution with specialised pollinators (Fenster et al. 2004). The flowers have long and narrow corolla tubes and require large-bodied, long-tongued bees for pollination. Anthophora plumipes (Pallas, 1772) (Hymenoptera: Apoidea: Apiformes) is a common pollinator of C. cava within the core of the plant's range, e.g. Austria, and its proboscis is 
long enough to reach the nectar legitimately. Queens of the long-tongued Bombus hortorum (L.) are also common pollinators within the plant's central range. This species forages legitimately both for nectar and pollen (Olesen and Knudsen 1994). Populations of C. cava at the margins of the species range exist without their principal evolutionary pollinators but persist through an interaction with local opportunistic flower foragers, including bees and butterflies (Olesen 1992, 1996; Olesen and Knudsen 1994). However, the flowers are visited mainly by freely foraging bumblebee queens. C. cava has two colour morphs (at least as recognised by humans): purple and white.

It is a well-known fact that flower colour is an important signal to pollinators and might influence pollinator behaviour (e.g. Waser and Price 1983; Welsford and Johnson 2012; Schiestl and Johnson 2013). When pollinators discriminate among colours, this may influence patterns of pollen transfer, and thus gene flow and evolutionary dynamics, within and between species (Hopkins and Rausher 2012). It is often assumed that many flowering plants owe much of their floral polymorphism in colour, shape and odour to the combined effects of attracting different pollinator species and to the spatio-temporal variation in the selection regimes they are subjected to (Ollerton et al. 2006). Many species of bumblebees have been shown to discriminate on the basis of floral colour (e.g. Waser and Price 1981, 1983; Lunau 1991; Lunau et al. 1996). Colour appears to be particularly important for flower recognition (Menzel and Schmidta 1993; Schiestl and Johnson 2013). Both honeybees and bumblebees learn colours quickly when they are rewarded according to colour choice (Heinrich et al. 1977; Gumbert 2000; Ings et al. 2009). Recent work has also indicated that the strength of innate colour preferences can influence foraging performance in bumblebees under natural conditions (Raine and Chittka 2007). Intraspecific pollinator discrimination may influence genotypic frequencies as well as the reproductive success of colour morphs in plants.

There have been studies focusing on bumblebee preferences for colour morphs where morphs differ in nectar content (Heinrich et al. 1977; Real
1981), variability of nectar content (Real 1981; Real et al. 1982), or the effects of density on pollinator preferences for colour morphs (Smithson and Macnair 1997). Previous studies have mainly focused only on a single bee species. Nevertheless, reality is more complicated because plants are pollinated by the whole pollinator community. What is interesting is the pollinator-plant relationship, especially in early spring when there are limited food resources. In this paper, we examine the pollinator community of $C$. cava. The purpose of our study was to verify the hypothesis that bumblebee queens differ in choice of flower colour morphs of C. cava.

\section{MATERIAL AND METHODS}

\subsection{Study organisms}

C. cava is a perennial spring forest herb with a complex flower. The plant grows in central and southern Europe and has either purple or white flowered individuals (see Supplementary Material). The terms "purple" and "white" refer to human colour space. According to Olesen and Knudsen (1994), ultraviolet reflection from flower parts, nectar production, pollen traits and scent chemistry do not differ between the two morphs.

Although the colour morphs co-occur throughout the range of the species, their frequencies vary. The frequency of white among populations ranges between 5 and $40 \%$, and within individual populations, white is often aggregated (Olesen and Knudsen 1994). Precocious flowering melliferous plants are of special importance, appearing directly before tree foliation. They precede and supplement shrub and tree flowering and are an important food supply for early spring bees.

The subgenus Bombus s. str. (syn. Terrestribombus) includes four species (Bombus terrestris, Bombus lucorum, Bombus cryptarum and Bombus magnus), with an additional fifth species in Fennoscandia (Bombus sporadicus). It is a group in which the classification of species is especially complicated (Bertsch et al. 2004). The lucorum complex from central and northern Europe comprises three monophyletic bumblebee taxa (B. cryptarum, B. lucorum and B. magnus), of which $B$. lucorum is the most common of the lucorum complex in Poland (Banaszak and Rasmont 1994). Because of the difficulty in separating the lucorum 
complex in the field even with freshly caught queens (e.g. in Scotland, Bertsch et al. 2005), we divided captured bumblebees from subgenus Bombus s. str. into $B$. terrestris and a second group of B. lucorum and B. cryptarum .

B. lucorum, B. cryptarum, B. terrestris, $B$. pratorum and $B$. lapidarius are short-tongued bumblebees (Pekkarinen 1979). On C. cava, these species behave as nectar robbers, biting a hole in the back of the corolla and inserting their proboscis through the hole to collect nectar. C. cava is nectar robbed but also pollinated by these short-tongued bumblebee queens (Olesen and Knudsen 1994; Olesen 1996). A longtongued bumblebee, B. hortorum, entered flowers through the front to collect nectar legitimately. $B$. hortorum is widespread and abundant throughout much of Europe. It is an unusual bumblebee in that it has a very long tongue, adapted for feeding on very deep flowers which other bees are unable to feed from.

\subsection{Methods}

Preliminary observations on pollinator visits to C. cava were recorded at two sites in spring 2011: Ocieszyn $\left(52^{\circ} 46^{\prime} \mathrm{N}, 16^{\circ} 50^{\prime} \mathrm{E}\right)$ and Miękowo (52 $29^{\prime} \mathrm{N}, 16^{\circ} 59^{\prime}$ E), both near Poznań, Poland. Subsequently, more extensive observations were made in spring 2014 at three sites: Ocieszyn, Miękowo and Radojewo (52 $\left.49^{\prime} \mathrm{N}, 16^{\circ} 95^{\prime} \mathrm{E}\right)$. All C. cava populations covered extensive areas and consisted of thousands of aggregated individuals. For estimation of colour ratios, we took photographs on a transect through the population at each site and in each year. Analysis of frequencies of the two colour types from ten photographs taken at each site/year estimated that $64.05 \%$ of flowers at Ocieszyn in 2011 were purple (508:905 white/purple), $48.43 \%$ at Miękowo in 2011 (524:492), $58.17 \%$ at Ocieszyn in 2014 (1113:1548), $48.59 \%$ at Miękowo in 2014 (1097:1037) and 61.99\% at Radojewo in 2014 (1089:1776).

To analyse flower colour discrimination by pollinators, flower-visiting sequences by randomly chosen individual bees were noted. Individual insects were tracked for an average of 24.4 visits (range 7-33). After observation, bumblebees were captured, identified to species and then released. The collected bumblebees were marked to avoid watching released individuals twice.

\subsection{Statistical analysis}

For each individual insect, the number and percentage of its visits to purple flowers were calculated. From each percentage, the appropriate site/year mean percentage of purple flowers was subtracted. This new variable, hereafter "colour bias", indicates colour preference relative to the site/year mean with positive values indicating more visits to purple flowers than expected and negative values indicating more visits to white flowers. The colour bias for each species was compared to zero using one-sample $t$ tests. Sparsely recorded species were not analysed. Differences between the three main species in colour bias were examined using one-way ANOVA.

The flower colour sequences of individual pollinators were analysed using runs tests to identify whether there was fewer colour switching, or more colour switching, than would be expected from random flower colour selection.

\section{RESULTS}

The plants were visited mainly by freely foraging bumblebee queens; the main species were the shorttongued bumblebees B. lucorum/cryptarum, $B$. terrestris and long-tongued $B$. hortorum. There were a small number of visits by two other bumblebee species $B$. pratorum and $B$. lapidarius. Visits by the hairy-footed flower bee $A$. plumipes and the honeybee Apis mellifera and the brimstone butterfly Gonepteryx rhamni were also recorded.

Foraging behaviour of 435 individuals was recorded (Table I). A total of 10,615 observations was made at the three sites as summarised in Table I. Pooling data across all individuals and species, $44.2 \%$ of visits were to white flowers and $55.8 \%$ to purple flowers, compared to an overall estimate of $57.1 \%$ purple flowers.

Limited numbers of individuals of some species meant testing was not possible (Table II). We have included samples as low as 5 for information only, but any results based on $n<20$ should be treated with caution. For B. lucorum/cryptarum, white flowers were used more often than expected at all site/years and this effect was significant for 4 of the 5 site/years and in the combined sample. The reverse was true for $B$. terrestris; purple flowers were preferred at all sites/years, and this was significant for three sites/years and in the 
Table I. Number of individual pollinators of Corydalis cava tracked at each site in western Poland.

\begin{tabular}{llllll}
\hline Species & $\begin{array}{l}\text { Ocieszyn } \\
2011\end{array}$ & $\begin{array}{l}\text { Miękowo } \\
2011\end{array}$ & $\begin{array}{l}\text { Ocieszyn } \\
2014\end{array}$ & $\begin{array}{l}\text { Miękowo } \\
2014\end{array}$ & $\begin{array}{l}\text { Radojewo } \\
2014\end{array}$ \\
\hline $\begin{array}{l}\text { Bombus lucorum (Linnaeus, 1761)/cryptarum } \\
\text { (Fabricius, 1775) }\end{array}$ & 11 & 20 & 41 & 50 & 24 \\
Bombus terrestris (Linnaeus, 1758) & 21 & 9 & 54 & 45 & 35 \\
Bombus hortorum (Linnaeus, 1761) & 2 & 4 & 23 & 32 & 45 \\
Apis mellifera (Linnaeus, 1758) & 7 & 0 & 2 & 0 & 0 \\
Gonepteryx rhamni (Linnaeus, 1758) & 1 & 0 & 0 & 0 & 0 \\
Bombus pratorum (Linnaeus, 1761) & 0 & 1 & 0 & 0 & 0 \\
Bombus lapidarius (Linnaeus, 1758) & 0 & 1 & 0 & 0 & 1 \\
Anthophora plumipes (Pallas, 1772) & 0 & 0 & 0 & 1 & 5 \\
No. of individuals [sum=435] & 42 & 35 & 120 & 128 & 110 \\
Total no. of observations [sum=10,615] & 850 & 722 & 3133 & 3350 & 2560 \\
\hline
\end{tabular}

Table II. A comparison of the colour bias of pollinators of Corydalis cava in western Poland using one-sample $t$ tests against a test value of zero, i.e. no bias.

\begin{tabular}{lllllll}
\hline Species & Site/year & Mean & SD & $\begin{array}{l}\text { Number of } \\
\text { samples }\end{array}$ & $t$ & $P$ value \\
\hline Bombus lucorum/cryptarum & Ocieszyn 2011 & -12.4 & 21.6 & 11 & -1.90 & 0.086 \\
& Miękowo 2011 & -35.8 & 18.9 & 20 & -8.45 & $<0.001$ \\
& Ocieszyn 2014 & -17.8 & 21.4 & 41 & -5.34 & $<0.001$ \\
& Miękowo 2014 & -12.1 & 19.0 & 50 & -4.49 & $<0.001$ \\
& Radojewo 2014 & -23.5 & 21.6 & 24 & -5.35 & $<0.001$ \\
& Combined & -18.8 & 21.6 & 146 & -10.57 & $<0.001$ \\
Bombus terrestris & Ocieszyn 2011 & 26.8 & 20.8 & 21 & 5.92 & $<0.001$ \\
& Miękowo 2011 & 3.4 & 20.8 & 9 & 0.5 & 0.633 \\
& Ocieszyn 2014 & 14.4 & 19.8 & 54 & 5.36 & $<0.001$ \\
& Miękowo 2014 & 7.8 & 27.4 & 45 & 1.91 & 0.062 \\
& Radojewo 2014 & 20.7 & 17.4 & 35 & 7.05 & $<0.001$ \\
Combined & 14.9 & 22.6 & 164 & 8.44 & $<0.001$ \\
Bombus hortorum & Ocieszyn 2014 & 5.6 & 18.7 & 23 & 1.43 & 0.167 \\
& Miękowo 2014 & 6.3 & 17.2 & 32 & 2.09 & 0.045 \\
Radojewo 2014 & 2.0 & 18.5 & 45 & 0.73 & 0.471 \\
Apis mellifera & Combined & 3.2 & 18.3 & 106 & 1.81 & 0.073 \\
& Ocieszyn 2011 & 9.2 & 35.2 & 7 & 0.69 & 0.514 \\
& Combined & -1.1 & 38.2 & 9 & -0.09 & 0.932 \\
& Radojewo 2014 & -7.0 & 43.9 & 5 & -0.36 & 0.740 \\
& Combined & 2.7 & 46.0 & 6 & 0.15 & 0.889 \\
\hline
\end{tabular}

Positive mean values indicate a bias to purple flowers, and negative mean values a bias towards white flowers. Tests are performed for each site/year and for the combined sample. Sample sizes $<5$ are ignored 
combined sample. For B. hortorum, there was a very slight preference for purple flowers. However, this was significant for just one site and not in the combined sample. Consequently, there is no strong evidence for a colour preference in this species.

A one-way ANOVA followed by Tukey HSD multiple comparisons confirmed that the mean colour bias of all three main Bombus species differed significantly from one another $\left(F_{2,413}=99.32\right.$, $P<0.001$; Figure 1). Runs tests generated $>10 \%$ significant fewer significant colour switching than would be expected from random colour sequences and no evidence for significant colour swapping in sequences (Table III). Ten of the B. terrestris individuals selected only purple flowers, emphasising the colour preference of this species.

\section{DISCUSSION}

The complex flower morphology of $C$. cava indicates a co-evolution with specialised pollinators. In early spring, its nectariferous flowers can be an important food supply. However, in early spring, the number of pollinators is strongly limited, especially among the bumblebee species, because the populations are restricted to overwintered queens. Therefore, due to this limited number of pollinators, the additional white morph can probably be considered a co-evolutionary adaptation to the development of another part of the pollinator community with different colour preferences.

However, a more probable cause of the emergence and maintenance of the colour polymorphism is negative selection by bumblebee species with colour preferences that behave as nectar robbers. Thus, in the case of increased abundance of B. lucorum/cryptarum, there would be increased costs for white flowering specimens while an increase in the number of $B$. terrestris would result in additional costs primarily for purple flowering specimens. This means that colour polymorphism is maintained by non-pollinator agents of selection (Strauss and Whittall 2006).

Plants with a specialised floral morphology may survive without these specialist pollinators
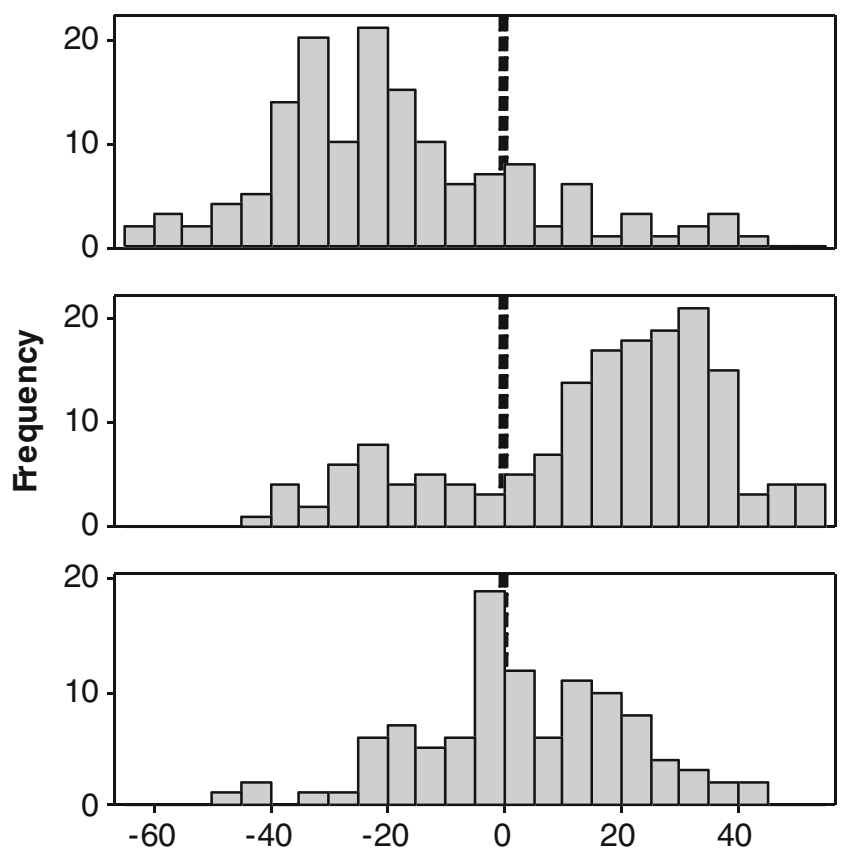

Figure 1. Flower colour bias in pollinators of Corydalis cava in western Poland. Histograms based on individual insects are shown for Bombus lucorum/cryptarum (top), B. terrestris (middle) and B. hortorum (bottom). Positive values, i.e. those to the right of the dotted vertical reference line indicate a preference for purple flowers and negative values a preference for white flowers. Data combined from all sites/years. 
Table III. The number of single-colour sequences and number of significant runs tests in Corydalis cava flower colour sequences by individual pollinators in western Poland.

\begin{tabular}{llllll}
\hline Species & $\begin{array}{l}\text { Number } \\
\text { of samples }\end{array}$ & $\begin{array}{l}\text { Number of } \\
\text { white-only } \\
\text { sequences }\end{array}$ & $\begin{array}{l}\text { Number of } \\
\text { purple-only } \\
\text { sequences }\end{array}$ & $\begin{array}{l}\text { Number of } \\
\text { significant runs } \\
\text { tests: fewer runs }\end{array}$ & $\begin{array}{l}\text { Number of } \\
\text { significant runs } \\
\text { tests: more runs }\end{array}$ \\
\hline Bombus lucorum/cryptarum & 146 & 3 & 2 & 17 & 0 \\
Bombus terrestris & 164 & 0 & 10 & 21 & 0 \\
Bombus hortorum & 106 & 0 & 1 & 15 & 0 \\
Apis mellifera & 9 & 1 & 1 & 0 & 0 \\
Anthophora plumipes & 6 & 1 & 3 & 0 & 0 \\
No. of individuals & 431 & 5 & 17 & 53 & 0 \\
\hline
\end{tabular}

The runs test compares the changes in flower colour by an individual pollinator with that expected from random colour choice. Fewer runs than random choice suggest deliberate colour selection. More runs than random choice suggest colour switching

at their range margin through pollination interactions with opportunistic flower foragers. This is the reason why the pollinator fauna varies between marginal and central range populations. In this situation, the foraging niche is shared between groups of pollinator species which compete for access to resources of nectar and pollen. According to several studies, C. cava in northern Europe is nectar robbed but also pollinated by the short-tongued bumblebee $B$. terrestris, whereas in central Europe, it is legitimately pollinated by A. plumipes males and $B$. hortorum queens (Olesen and Knudsen 1994; Olesen 1996). During our studies, we recorded pollination of $C$. cava mainly by queens of $B$. lucorum/ cryptarum, B. terrestris and B. hortorum and only occasionally by Anthophora plumipes, although the species is quite common in nearby habitats (Banaszak-Cibicka and Żmihorski 2012).

Our results highlight the existence of different preferences within the subgenus Bombus s. str. to the two flower colour morphs of $C$. cava during foraging. B. lucorum/cryptarum made more use of white flowers and $B$. terrestris more use of purple flowers. B. hortorum displayed no convincing preference for colour. These preferences are similar to the findings of Ings et al. (2009) who reported innate colour preferences of $B$. terrestris to blue flowers. However, the strength of this preference differs between populations and colonies. Probably in early spring, when bumblebee queens emerge from hibernation, innate colour preferences may protect against strong food competition. Eckhart et al. (2006) showed, in a community of pollinators foraging on colour and shape polymorphic plant species, that frequency of visits was correlated with particular morph frequency in the whole plant community. In contrast, in the Wahlenbergia albomarginata species representative of many New Zealand alpine herbs, the major pollinators, solitary bees, exerted no phenotypic selection for colour (Campbell et al. 2012).

Flowers send out signals to attract the attention of potential pollinators, and pollinators are attuned to particular traits, such as the colour, morphology, scent and temperature of the flowers they visit to find food (Menzel 1985; Dyer et al. 2006). Many plant species are known to have a variable corolla colour that covaries with other floral and biological traits (Griffiths and Ganders 1983). Those traits may influence pollinators which may preferentially visit one of the colour types. McCall and Primack (1992) found that flower colour was important in determining visitor identity. In other studies, flowering phenology (Herrera 1988) or the quantity of pollen or nectar reward offered (Bosch et al. 1997) were found to have a greater effect on visitor profiles than visible floral traits. According to Olesen and Knudsen (1994), ultraviolet reflection from flower parts, nectar production and scent chemistry did not differ between the two morphs of C. cava. 
There are many papers that show that bumblebees have an innate preference for "bee-purple" flowers (e.g. Briscoe and Chittka 2001; Chittka et al. 2004; Ings et al. 2009). In Chittka et al. (2001), seven species of bumblebees from three subgenera were tested: four from central Europe (B. terrestris terrestris, B. lucorum, B. pratorum and B. lapidarius), two from Asia (Bombus ignitus and Bombus hypocrita), and one from North America (Bombus occidentalis). All species showed a strong preference for shades in the violet-blue range.

We were interested in food flowers of $B$. lucorum, B. cryptarum and B. terrestris and their preferences for flower colour. In Poland, Ruszkowski (1971) listed 570 flower species which are food plants of B. terrestris and B. lucorum. However, he pooled data for these two bumblebee species, in common with many authors, because of the difficulty in separating among the bumblebees, especially workers, in the subgenus Bombus (Terrestribombus) in the field. Consequently, it is difficult to compare our results, where we separate these species, with some other studies.

For many authors, competition for resources is considered one of the main mechanisms of resource division and the main factor that could explain the local structure of the bumblebee fauna (e.g. Inouye 1977; Soltz 1987; Iserbyt et al. 2008). It is probable that competition for food resources in bumblebees is intense during spring since most of the food from flowers is limited at those times (Heinrich 1975). Patterns of food-gathering behaviour in bumblebees were shown to be governed by their relative tongue lengths, both directly when foraging for nectar (e.g. Brian 1957; Ranta 1984; Inoue and Yokoyama 2006) and indirectly when foraging for pollen (Prys-Jones and Corbet 1987) so that tongue length governs overlap in food use among bumblebee species (e.g. Ranta and Lundberg 1980; Hanski 1982). B. cryptarum/lucorum and B. terrestris are shorttongued bumblebees (Pekkarinen 1979). On C. cava, they behaved mostly as nectar robbers. These three species are very similar to each other, and identification is often difficult because they share a similar general appearance in colour and morphology. There are many papers that show the difference in ecology of $B$. terrestris and $B$. lucorum. B. terrestris dominates in open agricultural areas, and B. lucorum is more abundant in wooded areas but it has been considered widespread and abundant even in urban parks and gardens across Europe (e.g. Murray et al. 2008; Stanley et al. 2013). Little has been reported on the ecology of B. cryptarum, though it has been considered to be an early spring species whose phenology precedes that of B. lucorum (Bertsch 1997). It is possible that in this pollinator community, interspecific exploitation competition appears to be the primary mechanism involved in resource partitioning.

We believe, this knowledge can be useful for bumblebee conservation and enhancing pollinator diversity. Different colour preferences within very similar bumblebee groups suggest the necessity of providing different flower colours which can contribute to conservation of local fauna. We also believe that the results of our study should be taken into account when preparing agri-environment schemes designed to benefit pollinators.

\section{ACKNOWLEDGMENTS}

We would like to thank Dr. D. Moroń for his critical comments on an early version of this manuscript and $\mathrm{R}$. Andrzejczak for the help during field experiments.

\section{OPEN ACCESS}

This article is distributed under the terms of the Creative Commons Attribution License which permits any use, distribution, and reproduction in any medium, provided the original author(s) and the source are credited.

Les reines de diverses espèces de bourdons diffèrentelles dans leur choix d'une forme colorée de la fleur de Corydalis cava (Fumariaceae)?

Bombus lucorum / Bombus cryptarum / Bombus terrestris / Bombus hortorum / comportement d'approvisionnement / choix de la couleur

Gibt es bei Hummeln artspezifische Unterschiede in der Wahl der Farbmorphen von Corydalis cava (Fumariaceae)?

Bombus lucorum / Bombus cryptarum / Bombus terrestris / Bombus hortorum / Nahrungssammelverhalten / Farbwahl 


\section{REFERENCES}

Banaszak, J., Rasmont, P. (1994) Eucera Scopoli nouvelles pour la France (Hymenoptera, Anthophorinae). Bull. Soc. Entom. France 99, 165-168

Banaszak-Cibicka, W., Żmihorski, M. (2012) Wild bees along an urban gradient: winners \& losers. J. Insect Conserv. 16, 331-343

Bertsch, A. (1997) Abgrenzung der Hummel-Arten Bombus cryptarum und B lucorum mittels männlicher Labialdrüsen-Sekrete und morphologischer Merkmale (Hymenoptera, Apidae). Entomol. Gen. 22, 129-145

Bertsch, A., Schweer, H., Titze, A. (2004) Discrimination of the bumblebee species Bombus lucorum, Bombus cryptarum and Bombus magnus by morphological characters and male labial gland secretions (Hymenoptera: Apidae). Beit. Entom. 54, 365-386

Bertsch, A., Schweer, H., Titze, A., Tanaka, H. (2005) Male labial gland secretions and mitochondrial DNA markers support species status of Bombus cryptarum and B. magnus (Hymenoptera, Apidae). Insectes Soc 52, 45-54

Bosch, J., Retana, J., Cerdá, X. (1997) Flowering phenology, floral traits and pollinator composition in a herbaceous Mediterranean plant community. Oecologia 109, 583-591

Brian, A.D. (1957) Differences in the flowers visited by four species of bumble-bees and their causes. J. Anim. Ecol. 26, 71-98

Briscoe, A.D., Chittka, L. (2001) The evolution of color vision in insects. Annu. Rev. Entomol. 46, 471-510

Campbell, D.R., Bischoff, M., Lord, J.M., Robertson, A.W. (2012) Where have all the blue flowers gone: pollinator responses and selection on flower colour in New Zealand Wahlenbergia albomarginata. J. Evol. Biol. 25, 352-364

Chittka, L., Spaethe, J., Schmidt, A., Hickelsberger, A. (2001) Adaptation, constraint, and chance in the evolution of flower color and pollinator color vision. In: Thomson, J., Chittka, L. (eds.) Cognitive Ecology of Pollination, pp. 106-126. Cambridge University, Cambridge

Chittka, L., Ings, T.C., Raine, N.E. (2004) Chance and adaptation in the evolution of island bumblebee behaviour. Popul. Ecol. 46, 243-251

Corbet, S.A. (1995) Insects, plants and succession: advantages of long-term set-aside. Agr. Ecosyst. Environ. $\mathbf{5 3}, 201-217$

Dyer, A.G., Whitney, H.M., Arnold, S.E.J., Glover, B.J., Chittka, L. (2006) Bees associate warmth with floral colour. Nature 442, 525

Eckhart, V.M., Rushing, N.S., Hart, G.M., Hansen, J.D. (2006) Frequency dependent pollinator foraging in polymorphic Clarkia xantiana ssp. xantiana populations: implications for flower colour evolution and pollinator interactions. Oikos 112, 412-421

Fenster, C.B., Armbruster, W.S., Wilson, P., Dudash, M.R., Thomson, J.D. (2004) Pollination syndromes and floral specialization. Annu Rev Ecol Evol S 35, 375-403
Fussell, M., Corbet, S.A. (1991) Forage for bumble bees and honey bees in farmland: a case study. J. Apic. Res. 30, 87-97

Goulson, D. (2010) Bumblebees: behaviour, ecology, and conservation (No. Ed. 2). Oxford University Press, Oxford

Goulson, D., Hughes, W., Derwent, L., Stout, J. (2002) Colony growth of the bumblebee, Bombus terrestris, in improved and conventional agricultural and suburban habitats. Oecologia 130, 267-273

Griffiths, A.J.F., Ganders, F.R. (1983) Wildflower Genetics. Flight Press, Vancouver

Gumbert, A. (2000) Color choices by bumble bees (Bombus terrestris ): innate preferences and generalization after learning. Behav. Ecol. Sociobiol. 48, 36-43

Hanski, I. (1982) Communities of bumblebees: testing the core-satellite species hypothesis. Ann. Zool. Fenn. 19, 65-73

Heinrich, B. (1975) Bee flowers: a hypothesis on flower variety and blooming times. Evolution 29, 325-334

Heinrich, B. (2004) Bumblebee Economics: Revised Edition. Harvard University Press, Cambridge

Heinrich, B., Mudge, P.R., Deringis, P.G. (1977) Laboratory analysis of flower constancy in foraging bumblebees: Bombus ternarius and B. terricola. Behav. Ecol. Sociobiol. 2, 247-265

Herrera, C.M. (1988) Variation in mutualisms: the spatiotemporal mosaic of a pollinator assemblage. Biol. J. Linn. Soc. 35, 95-125

Hopkins, R., Rausher, M.D. (2012) Pollinator-mediated selection on flower color allele drives reinforcement. Science 335, 1090-1092

Ings, T.C., Raine, N.E., Chittka, L. (2009) A population comparison of the strength and persistence of innate colour preference and learning speed in the bumblebee Bombus terrestris . Behav. Ecol. Sociobiol. 63 , 12071218

Inoue, M.N., Yokoyama, J. (2006) Morphological variation in relation to flower use in bumblebees. Entomol. Sci. 9, 147-159

Inouye, D. (1977) Species structure of bumblebee communities in North America and Europe. In: Mattson, W.J. (ed.) The role of arthropods in forest ecosystems, pp. 35-40. Springer, Berlin, Heidelberg

Iserbyt, S., Durieux, E.A., Rasmont, P. (2008) The remarkable diversity of bumblebees (Hymenoptera: Apidae: Bombus) in the Eyne Valley (France, Pyrénées-Orientales). Ann. Soc. Entomol. Fr. 44, 211-241

Lunau, K. (1991) Innate flower recognition in bumblebees (Bombus terrestris, B. lucorum, Apidae): Optical signals from stamens as landing reaction releasers. Ethology 88, 203-214

Lunau, K., Wacht, S., Chittka, L. (1996) Colour choices of naive bumble bees and their implications for colour perception. J. Comp. Physiol. A 178, 477-489

McCall, C., Primack, R.B. (1992) Influence of flower characteristics, weather, time of day, and season on insect 
visitation rates in three plant communities. Am. J. Bot. 79, 434-442

Menzel, R. (1985) Learning in honey bees in an ecological and behavioral context. In: Lindauer, M., Hölldobler, B. (eds.) Experimental Behavioral Ecology, pp. 55-74. Gustav Fischer Verlag, Stuttgart

Menzel, R., Schmidta, A. (1993) The ecology of flower colours and the natural of flower vision of insect pollinators. The Israeli flora as a study case. Biol. Rev. 68 , $81-120$

Murray, T.E., Fitzpatrick, U., Brown, M.J., Paxton, R.J. (2008) Cryptic species diversity in a widespread bumble bee complex revealed using mitochondrial DNA RFLPs. Conserv. Genet. 9, 653-666

Olesen, J. M. (1992) How do plants reproduce on their range margin, in: Plant-animal interactions in Mediterranean-type ecosystems. Proceedings of the 6th International Conference on Mediterranean Climate Ecosystems pp. 117-122

Olesen, J.M. (1996) From naivete to experience: bumblebee queens (Bombus terrestris) foraging on Corydalis cava (Fumariaceae). J. Kansas Entomol. Soc. 69, 274-286

Olesen, J.M., Knudsen, J.T. (1994) Scent profiles of flower colour morphs of Corydalis cava (Fumariaceae) in relation to foraging behaviour of bumblebee queens (Bombus terrestris ). Biochem. Syst. Ecol. 22 , 231-237

Ollerton, J., Johnson, S.D., Hingston, A.B.. (2006) Geographical variation in diversity and specificity of pollination systems. In: Waser, N.M., Ollerton, J. (eds.) Plant-pollinator interactions: from specialization to generalization, pp. 283-308. University of Chicago Press, Chicago

Osgathorpe, L.M., Park, K., Goulson, D. (2012) The use of off-farm habitats by foraging bumblebees in agricultural landscapes: implications for conservation management. Apidologie 43, 113-127

Oster, G.F., Wilson, E.O. (1978) Caste and ecology in the social insects. Princeton University Press, Princeton

Pekkarinen, A. (1979) Morphometrie, colour enzyme variation in bumblebees (Hymenoptera, Apidae, Bombus ) in Fennoscandia and Denmark. Acta Zool. Fenn. 158, 1-60

Prys-Jones, O.E., Corbet, S.A. (1987) Bumblebees. Cambridge University Press, Cambridge

Raine, N.E., Chittka, L. (2007) Nectar Production Rates of 75 Bumblebee-visited Flower Species in a German Flora (Hymenoptera: Apidae: Bombus terrestris ). Entomol. Gen. 30, 191-192

Ranta, E. (1984) Proboscis length and the coexistence of bumblebee species. Oikos 43, 189-196

Ranta, E., Lundberg, H. (1980) Resource partitioning in bumblebees: the significance of differences in proboscis length. Oikos 35, 298-302
Real, L.A. (1981) Uncertainly and pollinator-plant interactions: the foraging behavior of bees and wasps on artificial flowers. Ecology 62, 20-26

Real, L.A., Ott, J., Silverfine, E. (1982) On the tradeoff between the mean and the variance in foraging: effect of spatial distribution and color preference. Ecology 63, 1617-1623

Ruszkowski, A. (1971) Rośliny pokarmowe i znaczenie gospodarcze trzmiela ziemnego - Bombus terrestris (L.) i trzmiela gajowego - B. lucorum (L.). Pamiętnik Puławski - Prace IUNG 47, 215-249

Schiestl, F.P., Johnson, S.D. (2013) Pollinator-mediated evolution of floral signals. Trends Ecol. Evol. 28, 307-315

Smithson, A., Macnair, M.R. (1997) Density-dependent and frequency-dependent selection by bumblebees Bombus terrestris (L.) (Hymenoptera: Apidae). Biol. J. Linn. Soc. 60 , 401-417

Soltz, R.L. (1987) Interspecific competition and resource utilization between bumblebees. Southwest. Nat. 32, 39-52

Stanley, D.A., Knight, M.E., Stout, J.C. (2013) Ecological variation in response to mass-flowering oilseed rape and surrounding landscape composition by members of a cryptic bumblebee complex. PLoS ONE 8(6), e65516

Strauss, S.Y., Whittall, J.B. (2006) Non-pollinator agents of selection on floral traits. In: Harder, L.D., Barrett, S.C.H. (eds.) Ecology and evolution of flowers, pp. 120-138. Oxford University Press, Oxford

Waser, N.M., Price, M.V. (1981) Pollinator choice and stabilizing selection for flower color in Delphinium nelsonii . Evolution 35, 376-390

Waser, N.M., Price, M.V. (1983) Pollinator behaviour and natural selection for flower color in Delphinium nelsonii . Nature 302, 422-424

Welsford, M.R., Johnson, S.D. (2012) Solitary and social bees as pollinators of Wahlenbergia (Campanulaceae): single-visit effectiveness, overnight sheltering and responses to flower colour. Arthropod Plant Interact. 6, 1-14

Williams, P.H., Osborne, J.L. (2009) Bumblebee vulnerability and conservation world-wide. Apidologie 40, 367-387

Wilson, E.O. (1971) The insect societies. Harvard University Press, Cambridge

Wilson, E.O. (1983) Caste and division of labor in leafcutter ants (Hymenoptera: Forrnicidae: Atta). III. Ergonomic resiliency in foraging by A. cephalotes. Behav. Ecol. Sociobiol. 14, 47-54

Winfree, R. (2010) The conservation and restoration of wild bees. Ann. NY. Acad. Sci. 1195, 169-197 